FIU Law Review

\title{
The Dormant Monster: Florida's Intrastate Marijuana Regulation and Its Susceptibility to Dormant Commerce Clause Challenge
}

Ivan Feris, Jr.

Florida International University College of Law, Iferi003@fiu.edu

Follow this and additional works at: https://ecollections.law.fiu.edu/lawreview

Part of the Commercial Law Commons, Constitutional Law Commons, Food and Drug Law Commons, and the State and Local Government Law Commons

Online ISSN: 2643-7759

\section{Recommended Citation}

Ivan Feris, Jr., The Dormant Monster: Florida's Intrastate Marijuana Regulation and Its Susceptibility to Dormant Commerce Clause Challenge, 15 FIU L. Rev. 457 (2021).

DOI: https://dx.doi.org/10.25148/lawrev.15.2.10

This Comment is brought to you for free and open access by eCollections. It has been accepted for inclusion in FIU Law Review by an authorized editor of eCollections. For more information, please contact lisdavis@fiu.edu. 


\title{
THE DORMANT MONSTER: FloridA'S InTRASTATE MARIJUANA REgULATION AND ITS SUSCEPTIBILITY TO Dormant COMmerce Clause Challenge
}

\author{
Ivan Feris $J r{ }^{*}$
}

\begin{abstract}
The United States lists marijuana as a schedule one drug, meaning that marijuana has a high potential for abuse, no medical uses, and is not accepted as safe by the medical community. Nevertheless, in recent years, states began legalizing marijuana at an increasing rate. It calls the question as to whether the federal prohibition of marijuana is an implied preemption over state regulation of marijuana and, thus, a limit on the state's power in creating their own regulation. Regardless of this question going largely unanswered, states have developed intricate regulatory infrastructures for their intrastate medicinal and recreational marijuana markets.

Supposing that the federal prohibition on marijuana is lifted and Congress permits states to legalize and therefore regulate the manufacture, production, and monetization of marijuana for medicinal and recreational purposes, would Florida's regulatory infrastructure be particularly susceptible to challenge under the dormant commerce clause? The question should be answered in the affirmative. Hence, this comment will discuss how Florida's intrastate marijuana regulatory system is vulnerable to challenge under the dormant commerce clause because it: (1) substantially burdens the free flow of interstate commerce; (2) discriminates against out-of-state actors; and (3) does not achieve the proposed local benefits by the least restrictive means. Finally, this comment makes recommendations on how Florida can modify its state regulatory scheme to avoid constitutional challenge.
\end{abstract}

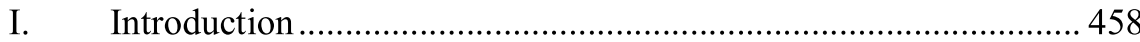

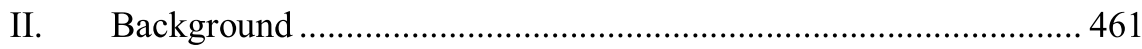

A. The History of Federal Marijuana Legislation......................... 461

B. Early Commerce Clause Cases ................................................ 463

C. The Dormant Commerce Clause ............................................... 467

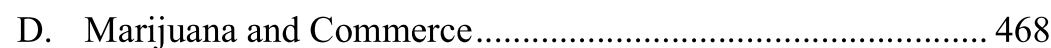

E. Intrastate Regulatory Frameworks ......................................... 471

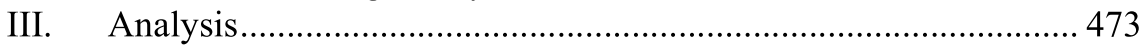

A. Florida's Marijuana Regulation and Its Substantial Burden on Interstate Commerce. 
B. Discrimination Against Out-of-State Distributors and

Consumers

1. Discrimination Against Out-of-State Vendors

2. Discrimination Against In-State Consumers and Out-of-State Patients in Florida's Marijuana Law 479

3. The Market Participant Exception to Discriminatory Action.

C. Putative Local Benefits in Florida Do Not Outweigh the Burden Imposed on Interstate Commerce.

IV. Recommendations for Reform 483

\section{INTRODUCTION}

Imagine that marijuana is made legal by Congress on a national level for both medical and recreational purposes. If that were the case, then people would be able to buy marijuana in any state they travel to, and individuals would be able to venture out into the marijuana business in any state of their choosing. However, when considering the marijuana regulatory schemes currently in place in certain states, such purchases and business endeavors would not be so simple. The current reality is that marijuana is illegal nationwide, ${ }^{1}$ yet many states have chosen to nonetheless legalize marijuana within their own borders, or at least decriminalize it to some degree. ${ }^{2}$ There is also a congressional bill that was introduced suggesting that marijuana should be legalized and regulated like alcohol. ${ }^{3}$ Yet another congressional bill was introduced, and passed in the house of representatives, that decriminalizes cannabis, removes cannabis from the schedule of controlled substances, and, inter alia, expunges the records of individuals convicted of cannabis offenses. ${ }^{4}$ If a bill similar to the ones mentioned were to pass as law, then state regulatory schemes in place today could potentially come under constitutional challenge.

It is important to understand the framework of governmental powers in order to understand where a constitutional dilemma might arise between federal and state legislation upon the legalization of marijuana. Under the Constitution of the United States:

\footnotetext{
* Juris Doctor, 2021, Florida International University (FIU) College of Law.

121 U.S.C.S. $\$ 812$ (b)(1) (2018).

2 Marijuana Overview, NCLS (Oct. 17, 2019), https://www.ncsl.org/research/civil-and-criminaljustice/marijuana-overview.aspx.

3 H.R. 420, 116th Cong. (2019).

4 H.R. 3884, 116th Cong. (2020).
} 
Laws of the United States which shall be made ... under the Authority of the United States, shall be the supreme Law of the Land; and the Judges in every State shall be bound thereby, any Thing in the Constitution or Laws of any State to the Contrary notwithstanding. ${ }^{5}$

Therefore, once Congress passes a law pursuant to a power granted to it by the Constitution, all states shall be bound by such laws; thus, states cannot promulgate law that contravenes those laws set out by Congress. Nevertheless, states still retain some power under the Constitution to ratify laws and govern their territories as their own sovereigns. For example, the Constitution states that " $[t]$ he powers not delegated to the United States by the Constitution, nor prohibited by it to the States, are reserved to the States respectively, or to the people." ${ }^{\circ}$ Logically, it should follow that states, therefore, would not be allowed to legalize the sale and use of marijuana due to the current federal ban; however, that issue is not as black and white as it may seem.

Theoretically, the federal law should trump the state laws that have decided to legalize marijuana in any form. For example, in Silkwood v. KerrMcgee Corp, the Supreme Court explained that state law can be preempted by a federal law in one of two ways:

If Congress evidences an intent to occupy a given field ... ; [or, i]f Congress has not entirely displaced state regulation over the matter in question, state law is still pre-empted to the extent it actually conflicts with federal law, that is, when it is impossible to comply with both state and federal law or where the state law stands as an obstacle to the accomplishment of the full purposes and objectives of Congress. ${ }^{7}$

Although Congress has not taken the power from the states to be able to legislate concerning marijuana outright, Congress listed marijuana as a controlled substance that has no medicinal value with a high risk for abuse. ${ }^{8}$ This makes it impossible for a state to legalize marijuana without being in direct conflict with the federal criminalization of marijuana.

Regardless of the obvious conflict of laws, many states continue to pursue the legalization of marijuana both for recreational and medicinal purposes. This has led to the exploration of this issue by many scholars who have explored the many facets of federalism and preemption issues that arise with marijuana legislation both between the federal government and states,

5 U.S. CONST. art. VI, cl. 2.

6 U.S. CONST. amend. X.

7 Silkwood v. Kerr-Mcgee Corp., 464 U.S. 238, 248 (1984).

$8 \quad 21$ U.S.C.S. $\$ 812$ (b)(1) (2018) 
and between states. For example, one scholar explored the ramifications of disputes that arise between states when one state has chosen to legalize marijuana while neighboring states have not, and which law should preempt the other. ${ }^{9}$ While another scholar wrote on the issues and differences of vertical (federal to state) and horizontal (state to state) preemption issues with marijuana. ${ }^{10}$ Several scholars have recognized that the commerce power is implicated by the marijuana industry and have discussed both commerce clause and dormant commerce clause concerns in their writing. ${ }^{11}$ There is no clear answer to these issues due to a lack of Supreme Court case law on the matter and lack of official action by Congress through legislation.

Despite the availability of lengthy commentary on commerce clause concerns in the marijuana industry, no scholar has yet juxtaposed a state's regulatory scheme to the commerce clause, under the assumption that marijuana is federally legal.

While the array of preemption issues that surround the marijuana industry cannot be easily explained away, the focus of this comment is on the narrow issue of the commerce power. Under the Constitution, Congress is given the power " $[t]$ o regulate Commerce with foreign Nations, and among the several States, and with the Indian Tribes." 12 Thus, taking into consideration the national trend of states legalizing marijuana, ${ }^{13}$ along with the potential legislation to legalize marijuana at a national level, ${ }^{14}$ this comment is written under the assumption, arguendo, that marijuana is legalized, or decriminalized and regulated, on a nationwide scale by Congress. Therefore, this comment will examine the implications of current marijuana regulation in Florida and consider how its intrastate regulatory system has an impact on Congress's power to regulate interstate commerce.

Thus, Part II of this comment will discuss the history of marijuana legislation and commerce clause jurisprudence, followed by a brief explanation of the current marijuana regulation in Florida and other states. Then, under the assumption that marijuana is legalized at a federal level, the analysis in Part III will discuss how Florida's current regulatory scheme for marijuana, if not reformed, might come under challenge pursuant to the

9 Robert A. Mikos, Making Preemption Less Palatable: State Poison Pill Legislation, 85 GEO. WASH. L. REV. 1, 5-6 (2017).

10 See generally Lea Brilmayer, A General Theory of Preemption: With Comments on State Decriminalization of Marijuana, 58 B.C. L. REV. 895 (2017).

11 See, e.g., Mark D. Rosen, Marijuana, State Extraterritoriality, and Congress, 58 B.C. L. REV. 1013 (2017); see also Chad Deveaux, One Toke Too Far: The Demise of the Dormant Commerce Clause's Extraterritoriality Doctrine Threatens the Marijuana-Legalization Experiment, 58 B.C. L. REV. 953 (2017).

U.S. CONST. art. I, $\S 8$, cl. 3.

3 See e.g., United States v. Harris, 890 F.3d 480, 487 (4th Cir. 2018)

14 See H.R. 420, 116th Cong. (2019); H.R. 3884, 116th Cong. (2020). 
dormant commerce clause because: (a) Florida's marijuana regulation substantially burdens the free flow of interstate commerce; (b) Florida's scheme discriminates against out-of-state vendors and consumers, acting in a regulatory capacity instead of as a market participant, and thus, may not engage in such discrimination; and (c) the discrimination does not further a legitimate state interest that outweighs the burden placed on interstate commerce through the least restrictive means. Finally, Part IV makes recommendations as to how Florida can amend its law to avoid future constitutional challenge in the wake of the marijuana revolution.

\section{BACKGROUND}

\section{A. The History of Federal Marijuana Legislation}

Marijuana (also known as weed, bud, grass, herb, and other euphemisms) is a mix of dried flowers that is smoked, usually for recreational purposes, in order to achieve a euphoric sensation known as a "high."15 These flowers are derived from the cannabis sativa plant, ${ }^{16}$ which grows indigenously in all areas of the world. ${ }^{17}$ The active ingredient in marijuana, which causes users to feel the high when smoking the flowers, is delta-9 tetrahydro-cannabinol (THC) ${ }^{18}$ While the flower is often used recreationally, it is also smoked and ingested through extracts such as vaporized oils, butters, wax, edibles, and other derivatives for medicinal uses. ${ }^{19}$ Some of the conditions that are treated by medicinal marijuana products include: Alzheimer's disease, cancer, Chron's disease, epilepsy, glaucoma, mental health, eating disorders, muscle spasms, nausea, and pain management. ${ }^{20}$ In addition to its medicinal and recreational uses, the cannabis sativa plant is also used to produce industrial hemp (containing lower levels of THC), which can be used in the creation of rope, clothing, twine, string and other coarse fabrics. ${ }^{21}$ Further, seeds produced from hemp are used as a health food

\footnotetext{
15 What Is Marijuana, NAT'L INST. DRUG ABUSE, https://www.drugabuse.gov/publications/research-reports/marijuana/what-marijuana (last visited Feb. 29 , 2020).

$16 I d$.

17 Tristen Hopper, Where Does Cannabis Grow Wild?, THEGrowthOP (Sept. 9, 2020) $\mathrm{https}$ ://www.thegrowthop.com/cannabis-culture/where-does-cannabis-grow-wild.

18 What Is Cannabis?, Alcohol \& DRUG ABUSE INST., https://adai.uw.edu/marijuana/factsheets/whatiscannabis.htm (last visited Feb. 29, 2020).

19 Medical Marijuana FAQ, WEBMD, https://www.webmd.com/a-to-z-guides/medicalmarijuana-faq (last visited Feb. 29, 2020).

20 Id.

21 Hemp, ENCYCLOPEDIA BRITANNICA, https://www.britannica.com/plant/hemp (last visited Feb. 29, 2020).
} 
alternative to dairy products because of their high protein, fiber, and magnesium content. ${ }^{22} \mathrm{Hemp}$ is also used to produce paints, varnishes, soaps, and bird feed. ${ }^{23}$

The use of the cannabis sativa plant, for the purposes previously mentioned, has found its place in human history and modern cultures. The use of marijuana as herbal medicine can be traced to Chinese culture as far back as 500 B.C. ${ }^{24}$ The use of recreational cannabis spread throughout Asia and Europe around 800 A.D., where nomads smoked marijuana seeds to achieve a high and practitioners of the Islam religion used hashish (a marijuana extract) ${ }^{25}$ Marijuana cultivation in America can be traced back to early colonists who produced industrial hemp to make fabrics in the $1600 \mathrm{~s}^{26}$ By the 1800s the use of medicinal marijuana extracts was widespread and could be found virtually anywhere. ${ }^{27}$ In the 1900 s, the recreational use of marijuana spiked in the United States, when Mexican immigrants (during the time of the Mexican Revolution) entered the States and introduced marijuana into the culture. ${ }^{28}$ By 1931, there was negative stigma surrounding the recreational use of the plant, and twenty-nine States outright prohibited marijuana usage. ${ }^{29}$

The first law to regulate marijuana at a federal level was the Marihuana Tax Act of $1937 . .^{30}$ The law aimed to charge "an occupational excise tax upon dealers of marihuana to impose a transfer tax upon certain dealings in marihuana, and to safeguard the revenue therefrom by registry and recording." ${ }^{31}$ Thus, while the Marihuana Tax Act was not an outright federal ban on marijuana, it effectively made the sale of marijuana almost wholly inoperable. ${ }^{32}$ The Act imposed exuberant taxes on the distribution of marijuana and required such extensive recording for the transactions that most dealers were unable to afford paying the taxes or to keep such detailed records; furthermore, failure to pay such taxes or keep such records was a criminal act. ${ }^{33}$ Therefore, this was the first sign of the federal government's

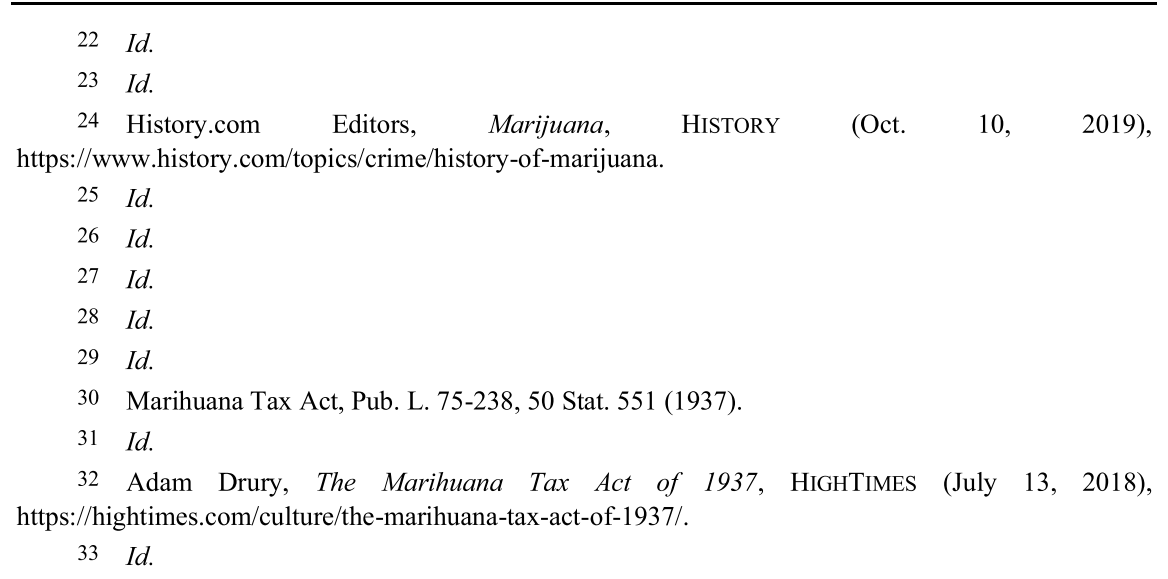


disapproval of marijuana, which became more robust over the decades to come.

Marijuana first became illegal in 1971 when the Federal Comprehensive Drug Abuse Prevention and Control Act of 1970 ("Controlled Substances Act") was enacted during the Nixon administration. ${ }^{34}$ The Controlled Substances Act placed marijuana in a category among other drugs, i.e., heroin and ecstasy, classifying it as a drug with a high potential for abuse and no recognized medical use; therefore, the act made it illegal for marijuana to be owned, prescribed, dispensed, or administered under federal law. ${ }^{35}$ From the 1970s until today, not much has changed with the legal status of marijuana, as marijuana is currently listed as a schedule one drug, which is the same classification it was given at the inception of the Controlled Substances Act. ${ }^{36}$

\section{B. Early Commerce Clause Cases}

Congress's ability to regulate interstate commerce has been the source of much legal discussion; the scope and parameters of Congress's power to regulate interstate commerce has been defined and refined through centuries of Supreme Court jurisprudence. At the inception of this case law, the Court stated that Congress's interstate commerce power encompasses the ability to regulate not only the interchange of commodities, such as buying and selling goods, but also the power to regulate the intercourse, or the navigation, of such interchangeable commodities ${ }^{37}$ However, this area of Congress's power is limited to commerce that takes place between different states, internationally, or when it involves Indian tribes. ${ }^{38}$ Thus, when Congress decides to regulate an area involving commerce between the states, any state laws directly in conflict with the regulations implemented by Congress are repugnant to the Constitution. ${ }^{39}$ While Congress's commerce power is restricted to commerce that involves interstate and not solely intrastate commerce, a regulation instated by Congress may incidentally affect the internal portions of a particular state's interstate commercial infrastructure. ${ }^{40}$ However, commerce that is totally internal to a state is left to be regulated by that state. ${ }^{41}$

34 Michael Gabay, The Federal Controlled Substances Act: Schedules and Pharmacy Registration, NCBI (May 29, 2013), https://www.ncbi.nlm.nih.gov/pmc/articles/PMC3839489/.

3521 U.S.C.S. $\S 812$ (c)(10) (2018).

36 Id.

37 See generally Gibbons v. Ogden, 22 U.S. 1 (1824).

38 Id. at $116-18$.

39 Id. at 45-48.

40 Id. at 243.

$41 \quad I d$. at 83. 
The Court later elaborated that while Congress may choose to regulate directly on a certain area of commerce, that does not necessarily imply that states cannot regulate in those areas as well. ${ }^{42}$ Unless Congress expressly excludes states from regulating a certain area of law, or that area of law is one that requires all states have a similar authority present, then states may also regulate commerce ${ }^{43}$ Thus, states may still hold some regulatory power in matters that deal with commerce even when Congress has chosen to regulate a certain field. For example, in Cooley, the state of Pennsylvania charged fees to certain vessels that used the state's ports when those vessels failed to operate under the direction of a pilot. ${ }^{44}$ Congress had the power to directly regulate vessels and navigable waters but chose not to directly regulate fees to be paid at certain ports. ${ }^{45}$ Thus, because the ports of each state are peculiar somehow, the absence of Congress directly regulating the ports implicitly leaves that power to the states. ${ }^{46}$ Therefore, states are able to regulate commerce, even when it implicates interstate commerce, so long as Congress has not already directly regulated that area and states are better suited to regulate it, considering the peculiarities found within that state. ${ }^{47}$

The Court expanded on this doctrine saying that states have a residuum of power to regulate commercial matters of local state concern when Congress has failed to regulate that area, even if they implicate interstate commerce, so long as: (1) a state regulation does not unduly burden the free flow of interstate commerce; (2) a state regulation does not interfere with the need for uniformity in a matter predominantly of national concern; and (3) the state interest is not outweighed by an interest of the federal government. ${ }^{48}$ In Southern Pacific, an Arizona law did not allow for a certain number of cars to be linked to the same locomotive for alleged safety concerns. ${ }^{49}$ Nevertheless, most locomotives throughout the nation did not run with such a low number of cars as that required in Arizona. ${ }^{50}$ Therefore, many trains would not be able to pass through Arizona as a result, creating serious delays in hauls and disrupting the uniformity of the railroad system nationwide. ${ }^{51}$ Moreover, there was no concrete proof that lowering the number of cars on locomotives would have any putative effect on the safety of the railroad

42 Cooley v. Bd. of Wardens, 53 U.S. 299, 318-19 (1852).

43 Id.

44 Id. at $311-12$

45 Id. at 318-19.

46 Id. at 319.

47 Id.

48 S. Pac. Co. v. Arizona, 325 U.S. 761, 766-67 (1945).

49 Id. at 763.

$50 \quad$ Id. at 771 .

51 Id. at 773 . 
system; rather, there was evidence to show that slack action in trains was actually the main cause of accidents. ${ }^{52}$ Taking all of these considerations into account, the Court held that the law was abhorrent to the Constitution because it unduly burdened interstate commerce and did not accomplish the safety goals for which it was implemented. ${ }^{53}$

Therefore, a state's power is limited when it regulates commercial activities, and states must be careful to neither unduly burden interstate commerce nor disrupt the uniformity of commerce that is of national concern. ${ }^{54}$ Ultimately, a balancing test is employed to determine whether the benefits of a state's proposed safety measure outweigh the interference created by the measure on interstate commerce; thus, a state may not simply list "safety" as the purpose of a regulation and use it as trump card on the burden created on the free flow of interstate commerce. ${ }^{55}$

Even though states hold power to regulate commerce that occurs solely intrastate, Congress has still invalidated state regulations that regulate intrastate activity because the application of such laws might have a harmful effect on interstate commerce ${ }^{56}$ For example, in Darby, Congress effectively excluded products (through labor and wage legislation) from the circulation of interstate commerce that were manufactured at an in-state factory where employees were being paid less than the federal minimum wage or were exceeding the federal maximum number of work hours. ${ }^{57}$ The Court held that Congress had the ability to exclude the products manufactured at a factory, which did not meet federal labor standards, notwithstanding that the work was performed solely in state and met local labor standards. ${ }^{58}$ Indeed, the Court explained that Congress may exclude products from interstate commerce that are not manufactured pursuant to federal labor standards because Congress's power to regulate interstate commerce is a plenary one, and no further limitations than those included in the Constitution are appropriate.$^{59}$ Congress's power to regulate interstate commerce allows it to set rules by which such commerce is governed, including the power to prohibit commerce. ${ }^{60}$

Also, the Court later held that the power to regulate interstate commerce allowed Congress to regulate intrastate activities that affect interstate

52 Id. at 766-67.

53 Id. at $781-82$.

54 Id. at $766-67$.

55 Id. at 780.

56 See, e.g., United States v. Darby, 312 U.S. 100 (1941).

57 Id. at $108-11$.

58 Id. at 114.

59 Id. at $113-14$.

60 Id. 
commerce and local incidents of interstate commerce, such as places of origin and destination. ${ }^{61}$ In the Heart of Atlanta Motel case, the Court further extended Congress's commerce power to regulate intrastate activity by ruling that Congress had the ability to prohibit a motel, which operated wholly intrastate, from discriminating against customers based on race. ${ }^{62}$ The motel operated completely within state borders; however, it serviced many out-ofstate commuters as it was at a location that was accessible via several interstate highways. ${ }^{63}$ Despite the motel's lack of activity outside of the state, the motel was sufficiently involved in interstate commerce that Congress retained the power to regulate the motel's activities to facilitate interstate commerce by any means that were necessary and proper.${ }^{64}$ Congress's ability to regulate the motel hinged on the fact that racial discrimination would obstruct interstate commerce by restricting the types of individuals that could travel to that state and find lodging; thus, Congress has the ability to regulate those local incidents of commerce. ${ }^{65}$ Therefore, when an enterprise operates solely within a state, but participates in business that involves interstate commerce, Congress may regulate the enterprise's commercial action regardless of state laws or the enterprises commercial inactivity outside of the state's borders. ${ }^{66}$

To be sure, Congress's power to regulate interstate commerce extends only to: (1) the channels of interstate commerce; (2) the instrumentalities of interstate commerce; and (3) any commercial actions that "substantially affect" interstate commerce ${ }^{67}$ Yet, Congress's plenary and broad power to regulate these areas of commerce cannot be wholly without consideration to the dual system of government in place in the United States. ${ }^{68}$ There is a balancing test in place that determines whether there is a rational relationship between Congress's regulation of an intrastate activity and that activity's substantial effect on interstate commerce. ${ }^{69}$ In sum, while the commerce power is a broad one, it is not an endless one.

Some industries function better under federal regulation. For example, the air travel industry performs more efficiently when it is uniformly regulated throughout all states, i.e., the Federal Aviation Administration

1 See generally Heart of Atlanta Motel v. United States, 379 U.S. 241 (1964)

Id. at $243-44$.

Id.

Id. at 258 .

65 Id.

$66 I d$. This is true so long as the activity involves interstate commerce.

67 United States v. Lopez, 514 U.S. 549, 558-59 (1995).

68 Id. at 557.

69 Id. 
regulates all air travel, at a federal level, for purposes of safety. ${ }^{70}$ However, this does not discount the need for states to regulate internal commerce and trade when it is necessary for the general welfare of the state. This is the constant interplay faced when considering the regulation of commerce and the division of power between the states and the federal government.

\section{The Dormant Commerce Clause}

Once the interplay between the federal and state government is acknowledged and understood, other questions might arise: What happens if Congress fails to regulate an area of interstate commerce whatsoever? Does this lead to the assumption that Congress intended to leave the power to regulate such an industry exclusively to the states? While the answer to the latter question is likely no, it introduces the topic of the judicially created doctrine of the dormant commerce clause.

At the inception of the dormant commerce clause doctrine, states had the power to regulate commercial areas unregulated by Congress, if such legislation was not repugnant to Congress's commerce power. ${ }^{71}$ For instance, when a state allowed for a dam to be built on navigable waters, a defendant challenged the sanctioning of the dam as repugnant to the federal commerce power because the dam was erected over a navigable water way. ${ }^{72}$ Nevertheless, the Court reasoned that because the construction of the dam was not repugnant to, i.e., did not interfere with, Congress's power to regulate commerce, the state was able to sanction the building of the dam regardless of the implications on interstate commerce. ${ }^{73}$ The test as to whether a state law is valid where Congress has not regulated an area of commerce has, however, narrowed with the passing of time.

A contemporary dormant commerce clause doctrine emerged. Under the contemporary doctrine, when Congress fails to regulate a certain area of interstate commerce, the Court first determines whether a state legislation has a substantial effect on interstate commerce. ${ }^{74}$ If the legislation substantially effects interstate commerce, the Court then determines whether the legislation discriminates against interstate commerce. ${ }^{75}$ State legislation that discriminates against interstate commerce is per se invalid unless it can pass

70 Mission, FAA, https://www.faa.gov/about/mission/ (last modified May 26, 2021, 2:50 PM) ("Our continuing mission is to provide the safest, most efficient aerospace system in the world.").

71 See generally Willson v. Black-Bird Creek Marsh Co., 27 U.S. 245 (1829).

72 See id. at 252.

73 See id.

74 See C \& A Carbone v. Town of Clarkstown, 511 U.S. 383, 389-90 (1994).

75 See id. 
muster under a strict scrutiny analysis, i.e., a least-restrictive-means test. ${ }^{76}$ In a second line of inquiry (referred to as the Pike test), used when there is no express discrimination against the flow of commerce, the Court determines whether the discrimination is excessive considering the putative local benefits proposed by the legislation. ${ }^{77}$ Thus: "[w]here the statute regulates even-handedly to effectuate a legitimate local public interest, and its effects on interstate commerce are only incidental, it will be upheld unless the burden imposed on such commerce is clearly excessive in relation to the putative local benefits." ${ }^{78}$ Whether the burden on interstate commerce created by a state regulation will be upheld as valid depends on the particular local interest in question and whether there is another reasonable alternative available to carry out that goal. ${ }^{79}$ These modern tests are used to determine whether a state law should be upheld as valid despite lack of legislation from Congress on the subject matter.

Thus, the dormant commerce clause is a way for the courts to prohibit states from impeding the free flow of interstate commerce and to promote comity amongst the states instead of engendering jealousies between the states. ${ }^{80}$ The commerce clause has been interpreted to invalidate state laws that impose barriers on commercial activity or products of commerce because of out of state origin. ${ }^{81}$ The logic behind the doctrine is clear in the name "United States." The nation is a united one and not a divided one; thus, the commerce power, despite not being overtly used by Congress, is in place to protect that unity between states.

\section{Marijuana and Commerce}

As discussed in previous sections, the commerce power is a broad and sweeping one that gives Congress the ability to regulate many areas of commercial activity. Like any other commercial activity, the sale of narcotics, i.e., controlled substances, is subject to regulation by Congress under the commerce power. ${ }^{82}$ "A major portion of the traffic in controlled substances flows through interstate and foreign commerce. Incidents of the traffic which are not an integral part of the interstate or foreign flow, such as manufacture, local distribution, and possession, nonetheless have a

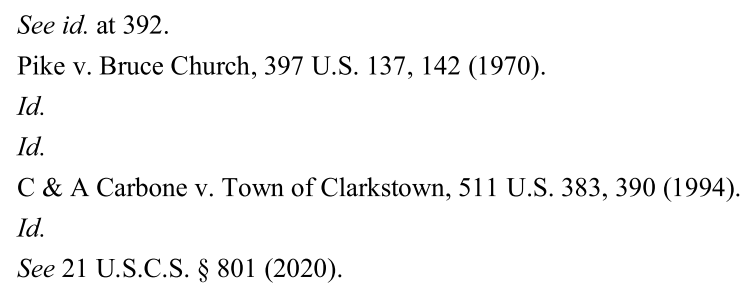


substantial and direct effect upon interstate commerce[.]" ${ }^{83}$ Even more, a controlled substance contained locally within a state is usually transported through interstate commerce ${ }^{84}$ Thus, all controlled substances, which are articles of commerce even if contained exclusively within the territory of a state, are implicitly subject to regulation by Congress through the power granted to Congress under the commerce clause. ${ }^{85}$

Marijuana is no exception. The Supreme Court has recognized that marijuana is an article of commerce that is subject to Congress's regulation. ${ }^{86}$ In Raich, California legalized marijuana for medicinal purposes; therefore, possession of marijuana by authorized individuals for medicinal use was not against the law. ${ }^{87}$ Nevertheless, federal agents seized and destroyed several cannabis plants from a California resident's home, who broke no California laws. ${ }^{88}$ The Court held that the actions of the federal agents were proper because the seizure was executed pursuant to federal legislation that regulated and criminalized the production of marijuana. ${ }^{89}$ While the marijuana seized and destroyed was exclusively for the personal use of the California resident, the action of harvesting the marijuana had a substantial effect on interstate commerce because individual growth could change the supply and demand regimen for the marijuana market (although illegal) nationwide..$^{90}$ Thus, marijuana, like any other commercial commodity put into the flow of commerce between states, is subject to regulation under Congress's commerce power.

At the present time, Congress has exercised its commerce power concerning marijuana. As previously noted, marijuana is currently listed as a schedule one substance under the Controlled Substances Act. ${ }^{91}$ Pursuant to its commerce authority, Congress chose to prohibit the marijuana market in the United States. However, despite the exercise of the commerce power by Congress in making marijuana illegal, there is a trend in states legalizing and decriminalizing marijuana nationwide. Courts have begun to acknowledge this trend and factor it into legal analysis when marijuana is an issue of importance in a case. ${ }^{92}$ Currently, there are thirty-six states that have

$83 \S 801(3)$

$84 \S 801(3)(\mathrm{B})-(\mathrm{C})$.

85 See U.S. Const. art. I, $\S 8$, cl. 3.

86 See generally Gonzales v. Raich, 545 U.S. 1 (2005).

87 See id. at 6-8.

88 See id.

89 See id. at 39-41.

90 See id.

9121 U.S.C.S. $\S 812$ (c)(10) (2020).

92 See e.g., United States v. Harris, 890 F.3d 480, 487 (4th Cir. 2018). 
legalized marijuana for medicinal purposes ${ }^{93}$ For example, Florida legalized marijuana for medicinal purposes, and Colorado legalized it for recreational use. ${ }^{94}$ Thus, contrary to the current federal ban of the substance, a majority of states have legalized the use of marijuana in some form.

Federal agencies have also been confronted by the marijuana trend. For example, the United States Patent and Trademark Office released an examination guide in 2019 discussing the protectability of marks used in the marijuana industry. ${ }^{95}$ The Trademark Office decided that, although states endorsed marijuana sales, a federal agency could not protect cannabis industry trademarks in contravention of the federal ban on marijuana. ${ }^{96}$ However, the Trademark Office could protect hemp product marks in compliance with the Farm Bill of 2018, which legalized hemp products nationwide. ${ }^{97}$ Federal banks have also felt the brunt of the power struggle between state legalization and the federal ban of marijuana operations. ${ }^{98}$

Members of Congress have also noticed the trend and foreshadowed that potential federal marijuana reform is on the horizon. ${ }^{99}$ The House of Representatives introduced a bill (the " 420 Bill") in 2019 that would potentially legalize marijuana nationwide. ${ }^{100}$ The House of Representatives also introduced, and subsequently passed, yet another bill in 2020 (The MORE Act of 2020), which calls for the decriminalization of cannabis nationwide, effectively eliminating any criminal sanctions for the possession, manufacture, or distribution of marijuana. ${ }^{101}$ The 420 Bill sought to make marijuana legal at a federal level, yet it would still be illegal to import marijuana into the United States or sell marijuana in interstate commerce without the proper permit. ${ }^{102}$ Permits under the 420 Bill would be administered by the Secretary of Treasury. ${ }^{103}$ Under the bill a person could

93 State Medical Marijuana Laws, NAT'L CONF. ST. Legislators (Feb. 19, 2021), https://www.ncsl.org/research/health/state-medical-marijuana-laws.aspx.

94 Fla. Stat. ANN. § 381.986 (LexisNexis 2019); Colo. Const. art. XVIII, § 16; State Marijuana Laws in 2019 Map, GOVERNING, https://www.governing.com/archive/state-marijuana-laws-mapmedical-recreational.html (last visited Feb. 21, 2021).

95 USPTO, EXAMINATION OF MARKS FOR CANNABIS AND CANNABIS-RELATED GOODS AND SERVICES AFTER ENACTMENT OF THE 2018 FARM BILL, EXAMINATION GUIDE 1-19 (2019).

96 Id.

97 Id.

98 See generally Symposium, Marijuana, Federal Power, and the States: Banks, Marijuana, and Federalism, 65 CASE W. RES. 598 (2015) (discussing federal banks and the possibility of facing prosecution when sanctioning legal cannabis businesses within a state due to the federal marijuana ban).

99 H.R. 420, 116th Cong. (2019); H.R. 3884, 116th Cong. (2020).

100 H.R. 420

101 H.R. 3884

102 H.R. 420

103 Id. 
have been disqualified from attaining a permit for several reasons including felony convictions, inability to comply with federal guidelines, or if the proposed course of action to be taken by the applicant would violate the state laws of the state in which the proposed action would be performed. ${ }^{104}$ Therefore, while Congress showed signs of potential change in how the marijuana market will be regulated, state laws will play a pivotal role in how the marijuana market will operate.

The 420 Bill considered the laws of the state or states within which a person seeks federal permission to engage in cannabis related business, ${ }^{105}$ suggesting that states will continue to play a role in the regulation of marijuana even if similar legislation is passed. Congress would likely show deference to state legislatures even if it decides to regulate the marijuana market on a nationwide scale. Thus, Congress is unlikely to preempt states from establishing regulatory measures for the marijuana industry on top of those imposed by Congress.

Although the 420 Bill never passed in either chamber of Congress, ${ }^{106}$ the House of Representatives showed support for the cannabis industry in introducing the bill. Further, the MORE Act of 2020 bolsters the support of legalization of cannabis from the House because it calls for complete decriminalization of cannabis nationwide, calls for the removal of cannabis as a scheduled substance, prohibits the denial of federal public benefits to a person on the basis of certain cannabis-related conduct or convictions, and prohibits the denial of benefits and protections under immigration laws on the basis of a cannabis-related event (among several other things). ${ }^{107}$

Despite the 420 Bill never being passed into law, ${ }^{108}$ the subsequent introduction of the MORE Act of 2020 suggests that nationwide legalization is still plausible. The trend toward legalization is evident. It is unclear what is to happen in the years to come. However, if this trend continues, then national legalization is undoubtedly a viable alternative. Thus, the analysis of Florida's regulatory cannabis infrastructure (conducted below) is done under the assumption that, arguendo, marijuana is legalized at a federal level.

\section{E. Intrastate Regulatory Frameworks}

With the trend of marijuana legalization comes unique legislation from the various states following the trend. Consequently, legislation from the 
states could substantially affect interstate commerce. While there is a lot of gray area between the conflict of the current ban on marijuana and the legalization of it in the states, the state regulatory infrastructures mentioned below are those currently in place in many states.

On the one hand, as of November 4, 2020, fifteen states and three different districts made way for expansive cannabis laws that legalize the recreational use of cannabis by adults. ${ }^{109}$ For example, Illinois has allowed the sale of recreational marijuana since January 1 st, $2020 .{ }^{110}$ Illinois made marijuana accessible to anyone over the age of twenty-one who can provide valid identification. ${ }^{11}$ Also, there is no discrimination to out-of-state residents who wish to get licensed to run a cannabis dispensing operation in Illinois, ${ }^{112}$ although some other parts of the industry have residency requirements before licensing. ${ }^{113}$ Colorado similarly makes marijuana accessible to adults over twenty-one and does not discriminate against outof-state residents from engaging in the marijuana market as distributors. ${ }^{114}$ Oregon also legalized marijuana. Initially, Oregon required in-state residency of two years or more for anyone seeking licensure to operate a marijuana growing facility, but it has since then repealed this requirement. ${ }^{115}$ Other states that have participated in the marijuana industry have chosen their own mode of regulation. ${ }^{116}$

On the other hand, Florida is a state where medical marijuana is legal. ${ }^{117}$ Florida's regulation has aspects within it that could substantially burden interstate commerce. For example, Florida has residency requirements for licensing both patients and individuals who wish to either use medicinal cannabis or be involved in its trade. ${ }^{118}$ Florida's regulatory infrastructure is the focal point of the following analysis, and Colorado's regulatory structure is, at times, used as a point of comparison. This analysis will demonstrate how Florida's scheme discriminates against interstate commerce without furthering a legitimate state goal whose importance outweighs the burden placed on interstate commerce. Therefore, this comment will analyze the

109 State Medical Marijuana Laws, supra note 93.

110 Sophia Tareen \& Corey Williams, Illinois Sees First Legal Sales of Recreational Marijuana, AP NEWS (Jan. 2, 2020), https://apnews.com/article/c7a1 fa6b60cd3a539fe095d116686d44.

111410 ILL. COMP. STAT. 705/10-25(a) (2019).

112 See 410 ILl. COMP. STAT. 705/15-25(d) (2019).

113410 ILl. COMP. STAT. 705/35-25(a) (2019) (infusers).

114 COLO. CONST. art. XVIII, $\S 16$.

115 OR. REV. STAT. $§ 475 B .450(2)(d)$ (2015) (repealed 2019).

116 See, e.g., NEV. REV. STAT. § 453D (2016) (no residency requirement); see also WASH. REV. CODE $\S \S 69.50 .325-395$ (2019) (no residency requirement).

117 See FLA. STAT. $\$ 381.986$ (2019).

118 FLA. STAT. $§ 381.986(5)(b)$ (2019). 
current regulatory scheme for marijuana in Florida, assuming that marijuana is federally legal.

Because it might be tempting for a state, such as Florida, not to change their laws even upon nationwide legalization for reasons such as bolstering their market economy, sheer inconvenience, or any other improper motivation, this paper will analyze how such a regulatory scheme contravenes the federal commerce clause power.

\section{ANALYSIS}

As previously mentioned, this comment is written under the assumption that marijuana is federally legalized, and that Congress has not preempted the regulation of the industry by states. If that were the case, then Florida's marijuana regulation, the focus of this discussion, could be subject to challenge under the dormant commerce clause.

The analysis section of this comment will be split up into three different subsections: (a) Florida's regulatory scheme for marijuana, and how it substantially affects interstate commerce; (b) the discriminatory aspects of Florida's scheme against out-of-state actors and products, and how that discrimination is improper pursuant to the "negative," or "dormant" commerce power of the federal government; and (c) how no cognizable putative state interest furthered by the Florida regulation is sufficient to outweigh the implications such regulation implements on interstate commerce.

\section{A. Florida's Marijuana Regulation and Its Substantial Burden on Interstate Commerce}

The Court has struck down many regulations and laws that burden interstate commerce. In Pike, for example, farmers successfully challenged an Arizona law that regulated the shipping of fruits and vegetables in interstate commerce. ${ }^{119}$ The law required that cantaloupes be of a certain quality and be packaged pursuant to the specifics set out in the law. ${ }^{120} \mathrm{~A}$ farm company did not have the ability to perform the packaging of the cantaloupes within the Arizona border without incurring high-level expenses. ${ }^{121}$ The farm company in turn began to deliver their cantaloupes to California, hours away, where they would be immediately packaged, despite an order that forbade

\footnotetext{
119 See generally Pike v. Bruce Church, Inc., 397 U.S. 137 (1970).

120 Id. at 138.

121 Id. at 144.
} 
such action. ${ }^{122}$ The Court decided that the application of the law was such that it created a substantial burden on the free flow of interstate commerce. ${ }^{123}$ The Court reasoned that when a state places a burden on interstate commerce by requiring commercial activities to be done in state that can be performed as efficiently, or otherwise more efficiently, out of state, such regulations are per se unconstitutional. ${ }^{124}$

The current Florida legislation requires all cultivation facilities to be located in state and licensed in state. ${ }^{125}$ Marijuana treatment centers cultivate and produce marijuana and marijuana products in the state of Florida. ${ }^{126} \mathrm{~A}$ grow facility or dispensary may only purchase product from another facility, which exclusively run in state, and can only make such a purchase if it can show it suffered a production failure. ${ }^{127}$ The Florida regulatory scheme separates the state into regions. ${ }^{128}$ The regulatory scheme not only limits the amount of centers that could be established, but also designates the regions where cultivation centers may be located within the state. ${ }^{129}$ Therefore, all marijuana products sold in Florida must be manufactured in the state of Florida. ${ }^{130}$ This can prove to damningly limit the resources available to individuals involved in the cannabis trade as well as substantially affect interstate commerce.

With the laws that are placed in Florida for the cultivation and production of marijuana products, a licensed treatment center could not choose to cultivate its marijuana out of state for in-state sale. This could seriously affect the financial state of treatment centers, which may find it cheaper to acquire facilities to perform cultivation out of state. A treatment center is also hindered from choosing to grow their product in a different environment out of state, even though better quality cannabis can be grown outside of the state of Florida. ${ }^{131}$ For example, it is common knowledge in the cannabis industry that "to grow marijuana outdoors, climate is everything." $" 132$ While it is true that marijuana grows indigenously around the world, not every climate is suitable for growing high-quality cannabis

22 Id.

123 See id. at 145.

124 Id.

125 FLA. STAT. § 381.986(8) (2019).

126 FLA. STAT. § 381.986(8)(a)(1) (2019).

127 FLA. STAT. $\$ 381.986(8)$ (c) (2019).

128 FLA. STAT. $\S 381.986(8)(\mathrm{a})(5)(\mathrm{b})$ (2019).

129 Id.

130 See FLA. STAT. § 381.986(8) (2019).

131 Gen. Hydroponics, Your Regional Guide to Growing Healthy Cannabis Plants Outdoors, LEAFLY (Dec. 28, 2017), https://www.leafly.com/news/growing/regional-guide-to-growing-cannabisoutdoors.

132 Id. 
outdoors; therefore, many cultivators have chosen to move their grow operations indoors in order to maintain their quality. ${ }^{133}$ Regardless of whether merchants choose to grow their cannabis outdoors or indoors in another jurisdiction, it could result in savings for the grower. The legislation in Florida has taken the choice away from merchants of where they can choose to cultivate their product.

Like the regulation in Pike, which required a certain standard quality of product and had packaging requirements that had to be completed in state, ${ }^{134}$ the Florida marijuana law similarly requires a certain level of quality in marijuana products and has packaging requirements that must be completed in state. ${ }^{135}$ Analogous to the regulation in Pike, the Florida regulatory scheme on the production and sale of marijuana is likely to have a substantial effect on interstate commerce. The Florida regulatory scheme only allows cultivation facilities to be placed within the state's borders and, therefore, limits the ability of producers to choose in which state to have their grow operations located. By doing so, Florida is burdening the choice of growers to engage in interstate commerce and potentially subjecting them to financial loss. Marijuana growers should be able to choose the state they produce their merchandise in. In Pike, farmers would have had to incur expenses that were too high to keep their farming business afloat if they chose to comply with Arizona's packaging requirement for cantaloupes and did so within Arizona's state borders. ${ }^{136}$ Similar expenses may result by restricting Florida cannabis farmers from being able to choose where their grow operations are located, potentially harming the business of small farmers.

For instance, in Alabama, a state that borders Florida, purchasing a property is thirty-three percent cheaper than the national average, and property taxes are the second lowest in the nation. ${ }^{137}$ This does not only correlate to property, but also to things like health insurance costs, which are lower in Alabama than any state in the nation. ${ }^{138}$ Considering the geographical proximity between Alabama and Florida, it is logical that businessmen operating a marijuana operation in Florida might be incentivized to lower their financial output, and maximize their profits, by placing their cultivation centers in Alabama and selling their products in Florida. By placing their cultivation centers in Alabama, growers would save on property expenses, i.e., lease expenses, or real estate purchase expenses.

133 Id.

134 Pike v. Bruce Church, Inc., 397 U.S. 137, 138 (1970).

135 FLA. STAT. $\$ 381.986(8)(\mathrm{e})(11)$ (2019).

136 Pike, 397 U.S. at 144.

137 Matthew Frankel, The 5 Cheapest States to Live in, MoTLEY Fool (Oct. 17, 2015, 6:28 PM), $\mathrm{https} / /$ www.fool.com/investing/general/2015/10/17/the-5-cheapest-states-to-live-in.aspx.

138 Id. 
This would not only benefit the farmers, which would save money, but such influx of business would also presumably contribute to Alabama's economy. In extreme circumstances, the savings that could be incurred by local marijuana farmers are potentially vital to keeping their businesses afloat. Such a restriction is likely to have a substantial effect on interstate commerce by restricting the free flow of commerce. Thus, by disallowing cultivators of cannabis from producing their product outside of state, which can be executed just as efficiently, Florida places a substantial burden on interstate commerce; hence, Florida's regulation is likely to create constitutional implications. ${ }^{139}$

Furthermore, Florida's regulatory scheme forbids a Florida production facility from purchasing marijuana products from any other production facility unless there is a proven cultivation error demonstrated by the facility who is in need of product. ${ }^{140}$ In addition, although not explicitly mentioned in the regulation, the Florida law does not allow sale outside of the state borders either to consumers or to other merchants. ${ }^{141}$ The Court, in Hughes, recognized that states may not prohibit the export of commerce to other states because doing so impermissibly burdens interstate commerce. ${ }^{142}$ There, a criminal defendant was charged, under Oklahoma law, for selling minnows to be shipped to, and sold in, Texas. ${ }^{143}$ The Oklahoma law prohibited the shipping of minnows outside of the state, and thus, Oklahoma charged the defendant. ${ }^{144}$ The Court held that such law was discriminatory and abhorrent to the Constitution because it inhibited the flow of interstate commerce. ${ }^{145}$

While the Florida statute does not directly mention that distribution facilities cannot ship out of state, the fact that distribution between facilities is prohibited except in cases of cultivation failure, and the fact that treatment facilities are only authorized to operate in state, implies that these facilities are unable to sell their product to someone in another jurisdiction. There is no reason, for example, why a Florida grower who had a grow failure, or even with no grow failure present, could not purchase their product from, say, a Colorado or a Nevada production facility. Or, even further, there is no reason why a facility could not be located wholly out of state, if more economically feasible or productive, and continue to sell the products in the state.

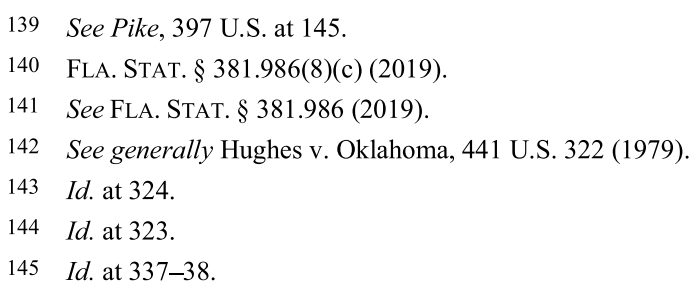


For example, the Colorado scheme treats marijuana like alcohol. ${ }^{146}$ While the regulatory scheme does not directly mention how that sale and growth is treated outside of state borders, extensive case law explains that states cannot unduly burden the distribution of alcoholic beverages between states. ${ }^{147}$ Therefore, the Colorado law is exemplary as to how Florida, and other states, should begin to structure their marijuana policies to allow the free flow of commerce between the states.

\section{B. Discrimination Against Out-of-State Distributors and Consumers}

As previously mentioned, when a state law discriminates against the flow of interstate commerce, the action will be deemed unconstitutional, unless it employs the least restrictive means available in furthering its proposed purpose. ${ }^{148}$ Therefore, because Florida's marijuana regulatory scheme discriminates against both out-of-state vendors and out-of-state consumers (patients), it raises a presumption of unconstitutionality. ${ }^{149}$

\section{Discrimination Against Out-of-State Vendors}

The Court has found that when a residency requirement discriminates against out-of-state actors when obtaining retail licenses, such a requirement might be deemed unconstitutional. ${ }^{150}$ For example, in Tennessee Wine \& Spirits, the Court decided that a Tennessee law that required an out-of-state actor to acquire at least two years of residency, among other residency requirements, before being eligible to attain a retail alcohol license was unconstitutional. ${ }^{151}$ The Court reasoned that Tennessee's law served merely a protectionist purpose and had an attenuated connection to public safety, unduly burdening the free flow of goods in the national market. ${ }^{152}$ At the crux of Congress's dormant commerce clause power lies the power to restrict states from unduly burdening interstate commerce by favoring its residents over other residents of other states. ${ }^{153}$ The Court found that the Tennessee law imposing a two-year residency requirement was discriminatory on its face. ${ }^{154}$ Further, the Court held that the Tennessee law had—at best—a highly

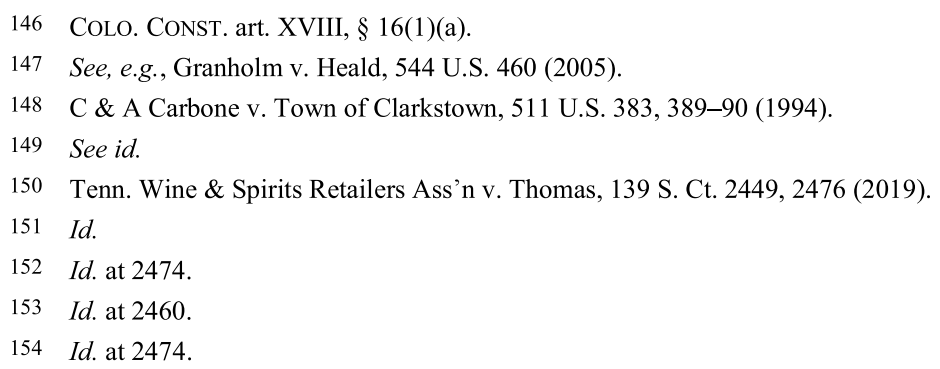


attenuated relationship to the general welfare of Tennessee and had an effect that preferred in-state actors as alcohol vendors, making the law unconstitutional. ${ }^{155}$

Similarly, Florida requires that any person who seeks to run a marijuana treatment facility be licensed to do business in Florida for five consecutive years before becoming eligible. ${ }^{156}$ Therefore, because it requires prolonged residency for any out-of-state actor to be able to run a treatment facility, the Florida law is discriminatory on its face. ${ }^{157}$ While it can be argued that this regulation is in place to promote the welfare of the state, and maintain control over the market, in reality all it does is give Florida residents an unfair advantage over out-of-state vendors. For example, there are other requirements for licensure in Florida that do not at all discriminate against out-of-state commerce and promote the general welfare of the state. These other licensure requirements include: possession of a valid certificate from the Department of Agriculture; the technological and technical ability to produce marijuana and low-THC-cannabis products; the ability to secure the premises, resources, personnel in the facility; and the ability to maintain and account for all raw material used to prevent them from going into the illegal market place. ${ }^{158}$ These other requirements are reasonable and go toward the pursuit of general welfare for Florida. Further, these other requirements do not discriminate against out-of-state commerce because an out-of-state actor can fulfill these requirements the same way that a Florida actor may.

Thus, for a state law that discriminates against out-of-state actors to be upheld, it must be narrowly tailored to further the interest proposed by the state. ${ }^{159}$ In Florida, there is no state interest furthered in a narrowly tailored fashion-other than preferential treatment of in-state residents-by establishing a residency requirement to obtain a retail license to distribute marijuana in the state. Therefore, akin to Tennessee Wine \& Spirits, where the Court held that Tenneesee's two-year residency requirement for a retail license to sell alcohol was unconstitutional, ${ }^{160}$ Florida's similar yet more stringent residency requirement (five years as opposed to two years) for licensure in marijuana distribution should be deemed unconstitutional.

This type of constitutional violation can be avoided in Florida by implementing nondiscriminatory requirements for licensure. For example, Colorado takes in as a primary consideration whether a person applying for a license to distribute marijuana has experience in growing marijuana and

155 Id. at $2474-76$.

156 FLA. STAT. § 381.986(8)(b)(1) (2019).

157 Tenn. Wine \& Spirits Retailers Ass' $n, 139$ S. Ct. at 2474.

158 FLA. STAT. $\S \S 381.986(8)(\mathrm{b})(2)-(6)$ (2019).

159 C \& A Carbone v. Town of Clarkstown, 511 U.S. 383, 389-90 (1994)

160 Tenn. Wine \& Spirits Retailers Ass ' $n, 139$ S. Ct. at 2476. 
experience in the municipality where licensure is sought pursuant to the Colorado code ${ }^{161}$ These considerations only come into play when the license applications are being competitively sought; otherwise there is no requirement to have a connection with Colorado and thus no discrimination against out-of-state commerce. ${ }^{162}$ Therefore, marijuana laws like those in Colorado should be implemented by states like Florida whose current marijuana laws have discriminatory aspects.

2. Discrimination Against In-State Consumers and Out-of-State Patients in Florida's Marijuana Law

When a state has legalized instrumentalities of commerce to be used in a state and those instrumentalities are produced in a state, it cannot prohibit individuals from buying that same product out of state. ${ }^{163} \mathrm{In} S \mathrm{Scott}$, the Court held that when South Carolina allowed the manufacture and sale of alcohol within its state borders, it could not prohibit its residents from purchasing alcohol out of state. ${ }^{164}$ There are similarities between Florida's marijuana scheme that requires consumers to be residents of Florida, be registered on a state registry, and purchase their medicine solely form in state merchants, ${ }^{165}$ and the South Carolina regulation in Scott, which required South Carolina residents who wanted to partake in the consumption of alcohol to purchase their alcohol only in state. ${ }^{166}$ Florida residents, who may legally purchase medicinal marijuana within Florida borders, should be able to purchase their medicinal marijuana from another state if they so choose; thus, because Florida law prohibits resident consumers from purchasing cannabis outside of the state, the law is discriminatory and could face constitutional scrutiny. ${ }^{167}$

Moreover, the residency requirement to become a qualified patient offends individuals' right to travel and impinges on equal protections of laws and an individual's privileges and immunities. ${ }^{168}$ For example, in Saenz, California implemented legislation that limited the amount of welfare benefits that a person in California could receive. ${ }^{169}$ The only way that a California resident would be eligible to receive the full amount of benefits

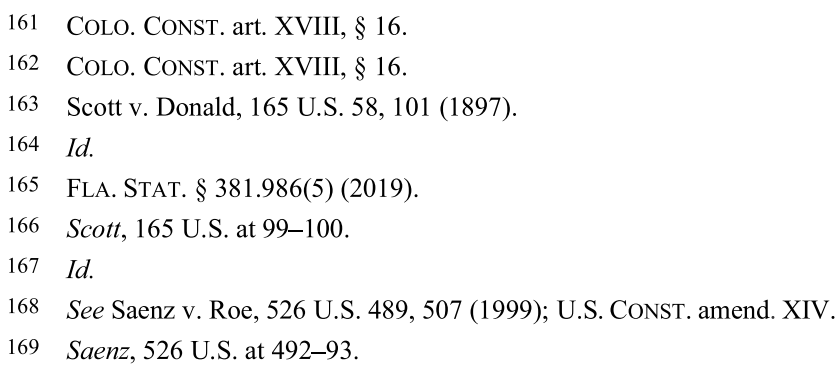


offered by the state would be to live in California for at least twelve months. ${ }^{170}$ The Court reasoned that such a regulation impinged upon the right to travel, a fundamental right; therefore, for a such requirement to be upheld, it must be necessary to further a compelling state interest. ${ }^{171}$ The right to travel includes the ability to freely move amongst the states and to be treated equally in every state where one goes. ${ }^{172}$ Thus, the California statute was deemed unconstitutional for not allowing out-of-staters the ability to receive the full amount of welfare benefits. ${ }^{173}$

Before a person can become a qualified patient in Florida, making them eligible to purchase marijuana in the state, that person must prove they are a resident or temporary resident of the state of Florida. ${ }^{174}$ To prove permanent residency, a person is required to attain some form of Florida identification; while to be deemed a temporary resident, a person is required to show a proof of address, through receipt of mail, where the individual is residing. Without such proof, a person is not eligible for licensure in the registry of patients, rendering that person ineligible to purchase medicinal marijuana in the state of Florida. ${ }^{175}$ Therefore, a person must be living in Florida, at least temporarily, to be able to purchase marijuana in Florida. ${ }^{176}$ This restriction does not consider, for example, a traveler on vacation in Florida who is a qualified patient in another state and has a necessity for marijuana. How will that person get his medicine while in Florida? This type of discrimination could violate equal protection principles and the privileges and immunities clause because it restricts the right to travel without being necessary to further a compelling state interest. ${ }^{177}$

In order to avoid this type of constitutional implication Florida can make it so that any person who is eligible to purchase medicinal marijuana in another state, can also be eligible to purchase medicinal marijuana in the State of Florida. For example, Colorado's scheme on the regulation of marijuana allows any person over 21 years old to purchase marijuana. ${ }^{178}$ This age requirement does not infringe upon the right to travel because any person from any state who is of the required age is able to purchase marijuana. Therefore, Colorado's standard for purchasing marijuana is more attainable and imposes fewer barriers on commerce and individuals' liberty interests

$170 \quad I d$.

171 Id. at 504-07.

172 Id. at $500-04$.

173 Id. at $508-10$

174 FLA. STAT. $\S 381.986(1)(1),(5)(b)$ (2019).

175 FLA. STAT. \$ 381.986(5)(b) (2019).

176 See id.

177 See Saenz, 526 U.S. at 502-10.

178 Colo. Const. art. XVIII, $§ 16$. 
than the legislation in Florida. If Florida wished to restrict the sale of marijuana to only certain qualified individuals, it may do so; but it should not inhibit citizens' right of travel in doing so.

\section{The Market Participant Exception to Discriminatory Action}

The market participant doctrine allows states to give preferential treatment to their residents when the state acts as a market participant rather than a market regulator, making such preferential treatment constitutional pursuant to the commerce clause. ${ }^{179}$ In White, a Boston mayor implemented an executive order which required that all construction projects that were funded wholly by city funds had to include a minimum of at least fifty percent of laborers who were residents of Boston. ${ }^{180}$ Some employers challenged this order as unconstitutional under the commerce clause, claiming it discriminated against out-of-state laborers. ${ }^{181}$ The Court decided that when a state acts as a market participant, i.e., placing its own funds up for the construction project, it is not subject to the Commerce Clause. ${ }^{182}$ The Court further held that if a state is authorized to act by Congress, then its action does not implicate the commerce clause even if it constricts interstate commerce. ${ }^{183}$

Florida acts as a licensing agency and as a market regulator rather than a market participant. Florida does not put up its own money to finance cultivation, nor does it receive federal funds, which are sanctioned by Congress, to do so. If Florida were to grow its own marijuana, it would validly be able to sell marijuana at discounted prices to in-state vendors. It may also give certain benefits to in-state consumers when acting as a market participant. It might even be able to limit most, if not all, marijuana sales to out-of-state individuals in times of scarcity. ${ }^{184}$ However, Florida does not act in a market participant capacity under its regulatory scheme; thus, Florida's discriminatory action could come under challenge pursuant to the dormant commerce clause. Therefore, Florida should look to remove discriminatory provisions from its marijuana regulatory scheme.

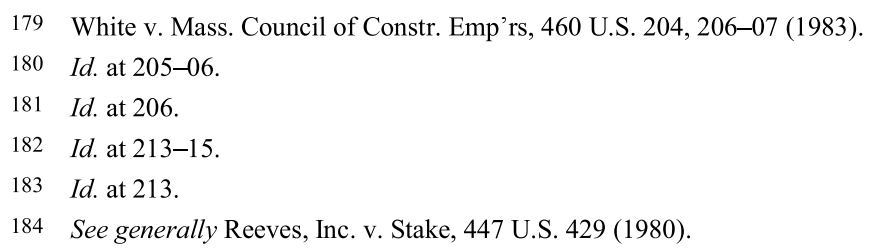




\section{Putative Local Benefits in Florida Do Not Outweigh the Burden Imposed on Interstate Commerce}

Once a state law is determined to discriminate against interstate commerce, either on its face or in effect, then the state law will be upheld only if it furthers a legitimate state interest using the least restrictive means available. ${ }^{185}$ This test is a strict scrutiny analysis, which is more demanding than the test used when a law incidentally discriminates against interstate commerce (being a balancing test as to whether local benefits rationally justify the impact on interstate commerce) ${ }^{186}$ In Taylor, a criminal defendant was charged with violation of a statute that made it illegal to import live baitfish into the state of Maine. ${ }^{187}$ Maine argued that the statute was in place to prevent the transmission of parasites from baitfish found in other states that were not found in the natural aquatic life of Maine. ${ }^{188}$ This was done to avoid potential harm from being inflicted on the wildlife in Maine. ${ }^{189}$ The Court found that the ban, although subjected to the strictest scrutiny, passed the least restrictive means test. ${ }^{190}$ The reasoning was that, at the time that controversy arose, there was no accepted scientific method to sample live bait fish. ${ }^{191}$ Therefore, in order to test the baitfish for parasites, the baitfish would have to be destroyed, rendering them useless. ${ }^{192}$ Thus, although scientific methods might have been developed to test baitfish in the future, there was no alternative means to avoid parasites endangering the aquatic wild life in Maine other than to prohibit the importation of live baitfish. ${ }^{193}$

In another case, Dean Milk Company, the Court held that although a state had a legitimate interest in having milk that met high health standards, the interest was insufficient to allow discrimination against interstate commerce because it was not pursued by the least restrictive means. ${ }^{194}$ There, a locality did not license a company to sell milk in their jurisdiction because the milk was being pasteurized more than five miles away from the city limits. ${ }^{195}$ The Court reasoned that the same health standards that were required in the locality could be achieved by alternative means that were not

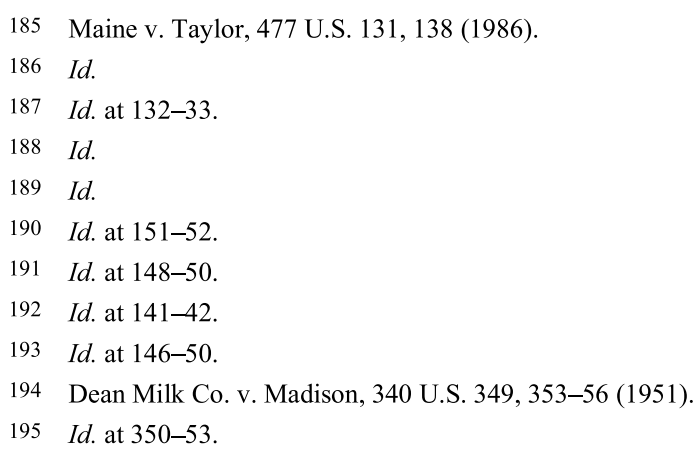


as restrictive on commerce. ${ }^{196}$ For instance, the milk could be tested before being sold, ensuring that it met the appropriate health standards required by the municipality. ${ }^{197}$ Thus, the Court held that because the state action did not meet the strict scrutiny standard, and only served to boost the financial interests of the local economy, it was unconstitutional. ${ }^{198}$

As mentioned before, marijuana that is sold in Florida must also be cultivated in Florida and may not be imported from an outside state. If strictly scrutinized, Florida's regulation is unlikely to pass constitutional muster. Unlike Taylor, where Maine had no recognized method to keep parasites out of their wildlife other than to prohibit importation of live baitfish, ${ }^{199}$ Florida does have other means available, which are not as restrictive, to promote the health and safety of locals.

For example, the Florida statute regulates how marijuana should be grown, what chemicals can be used in its production, and how it will be determined safe for human consumption after the fact. ${ }^{200}$ There is a final test that is necessary to ensure the safety and quality of all the marijuana product to be sold in Florida. ${ }^{201}$ Florida should be able to test all the incoming cannabis products to certify that they meet a consumable human safety standard, just as Florida currently tests all products that are produced in state. ${ }^{202}$ Florida can still promote the health and safety of its citizens without discriminating against out-of-state commerce. Florida's law is subject to challenge because, like in Dean Milk where tests were available to ensure health standards for milk before sale, Florida is able to test cannabis before sale as a form of quality control. ${ }^{203}$ Therefore, Florida does not employ the least restrictive means in its marijuana regulation, making the regulation susceptible to constitutional challenge.

\section{RECOMMENDATIONS FOR REFORM}

In sum, given the trend towards marijuana legalization in the United States, Congress should consider either explicitly prohibiting states from regulating and allowing marijuana trade or otherwise legalizing marijuana on a nationwide level. Either one of these options would be enough to minimize the current power struggle between the states that have chosen to legalize

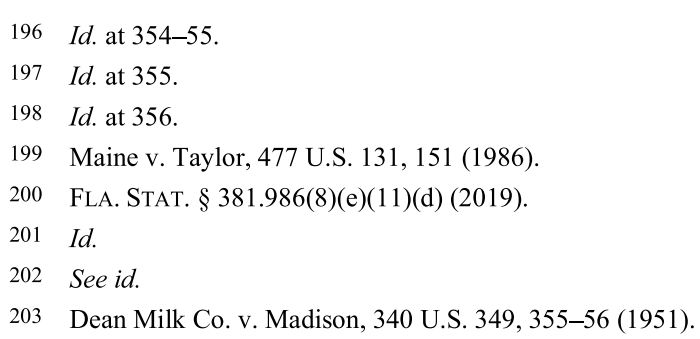


marijuana and the federal legislature. Assuming the second alternative is chosen by Congress, then states, i.e., Florida, should reform their regulatory schemes in order to avoid potential constitutional challenge.

Florida's current marijuana legislation could become susceptible to constitutional challenge under the dormant commerce clause doctrine, in the wake of a nationwide legalization, because: (1) Florida's current regulatory scheme will create a substantial burden on interstate commerce; (2) Florida's current regulatory scheme expressly discriminates against out-of-state consumers and out-of-state individuals wanting to enter the marijuana business in Florida; and (3) the discrimination in the Florida regulation does not further any local putative benefits in the least restrictive way available.

For this reason, before Congress legalizes marijuana, Florida should reform its statute. For example, in-state consumers should be allowed to purchase cannabis outside of the state of Florida. Florida should also consider enacting regulations that either eliminate a registry for consumers of marijuana or that allow consumers registered in other states to purchase their cannabis in Florida. The best option in this regard is to mirror Colorado, which allows anyone who is above twenty-one years of age to partake in the purchase and consumption of marijuana.

Another policy that Florida should reconsider is its five-year residency requirement for an applicant who wishes to open a treatment facility. Florida should remove a residency requirement altogether to avoid any type of constitutional challenge based on discrimination. Florida can apply other requirements such as financial capacity, industry savviness, and familiarity with local guidelines to weed out unworthy applicants (no pun intended). Further, Florida should legislate around the implicit requirement that a marijuana treatment center cannot purchase marijuana it endeavors to sell in Florida from outside of the state. Indeed, there is no reason why a treatment facility cannot operate its cultivation operations wholly out of state and then perform its distribution solely within the state of Florida; this too should be reflected in the regulation.

Ultimately, the main protection Florida should be concerned about is one that is already in place and requires no reform: the requirement of testing cannabis products to ensure they are safe for human consumption. This alone is sufficient to achieve any safety standard sought by the state, making any discriminatory provision wholly unnecessary. While some restraints, such as regulations on packaging marijuana and zoning laws that effect the placement of a treatment or cultivation facility, may be adequate to control the cannabis industry; those restraints that discriminate against out-of-state actors are not. Considering the renown quote by Justice Cardozo saying, "the peoples of the several states must sink or swim together, and that in the long run prosperity 
and salvation are in union and not division," ${ }^{204}$ Florida should abolish any discriminatory regulation from its regulatory scheme for marijuana.

Florida should prepare for congressional action in the cannabis sector, and, therefore, it should get ahead of the curve and reform its marijuana regulation, to avoid future challenge under the dormant commerce clause. Other states should take heed and do the same.

204 Baldwin v. G.A.F. Seelig, Inc., 294 U.S. 511, 523 (1935). 